Article

\title{
Industrial Risk in Thessaloniki and Urban Regeneration Context
}

\author{
Christine Matikas * \\ Architect Engineer, University of Thessaly, Urban Planner, DSA ENSA Paris La Villette \\ E-Mail: titina_x@hotmail.com
}

* Author to whom correspondence should be addressed; Tel.: +306944664396, V.Kornarou 20, 54655, Thessaloniki, Greece

Received: / Accepted: / Published:

\begin{abstract}
The venture of Industrial Risk concerns life, natural - built environment and socioeconomic activities. The aim of the research is to identify the threat, its awareness and to ensure the protection of residents. Activities that can lead to a Major Accident (MA), installation process of new units - establishments and responsibilities of investors and the state, are indicated in European Directives, called SEVESO. Employers have responsibility for safety within the industrial establishment; the state is responsible for the perimeter. So governments are responsible for the methods determining the Protection Zones (PZ), the expected impacts of a MA per zone and the Major Accident Prevention Policy (MAPP). In Greece these arrangements are not a result of institutionally entrenched methodological choices. For the first time, new SEVESO installations are related to Land Use Planning in the Directive SEVESO II of 1996, without referring to the existing proximity of corresponding activities to the urban fabric. Western Thessaloniki is the territory in danger. It is established the fact that the parameter of industrial risk is absent from the urban planning of the area. The urban paradox of residents' coexistence to the risk (threat) is probably caused by the diachronic vicinity of urban tissue with industries, without any relative preoccupation, despite occasional incidents. There is not a fauve impact just because of ignorance and lack of information, despite any clear provision from Directives SEVESO. The correlation of existing protection zones with urban areas, where anticipated impacts in case of major accident, shows a series of conclusions concerning terms and conditions of coexistence.
\end{abstract}


Keywords: Industrial Risk, SEVESO Major Accident, Impact Fauve, Socio-economic Damage, Urban Regeneration.

\section{Introduction}

This paper focuses on industrial risk, as identified in absolutely specific area, that of Thessaloniki, and in a context of urban preventive interventions, aimed at reducing the consequences of a possible industrial accident (MA) in that area. To sum up, my thinking process touches: a. the notion of industrial risk and its impact on specific urban zones, b. the technical and financial possibilities for risk reduction and spatial socioeconomic consequences locally, regionally and nationally, c. the approach of alternative proposals in medium and long term and $d$. the beginning of immediate actions.

\section{Results and Discussion}

The methodology followed in this research work, was restructured several times to meet its goals, preoccupations and questions raised. The lack of adequate primary data on the industrial risk was a key difficulty combined with the difficulty of correlation of different approaches and technological data of various scientific sectors.

The final form of the research methodology is summarized in the following steps:

a) The survey of the current state of natural environment (physical) social and economic.

b) The relationship between activities, industries and economic sectors. The role of industry.

c) The industrial risk (SEVESO II) and the dangers that arise both for population and environment, physical and built.

d) The role of dangerous industrial establishments in the context of productivity, growth and development of the local economy and the impact in case of relocation or closure.

e) The correlation between risk reduction and alternative proposals.

f) The direct actions on the urban fabric.

The research is structured into three major parts, each of which contains chapters and these in their turn other subsections.

The first part focuses on the city of Thessaloniki, in Greece (Figure 1). Specifically, the region of central Macedonia (Figure 2) is approached, in the sense of the greater metropolitan area, concerning its geography, natural environment, population, economy and planning. Moreover, the urban area of Thessaloniki (Figure 3) is analyzed, with particular references both to Masterplan and its actualization and to the diachronic evolution of population and the structural characteristics. The city of Thessaloniki constitutes the next reference point; especially the expansion of urban tissue and the urbanization. There are also references to the history of industrialization of the city, the current situation and issues of atmospheric pollution and green spaces.

Figure 1. The Region of Central Macedonia in Greece. 


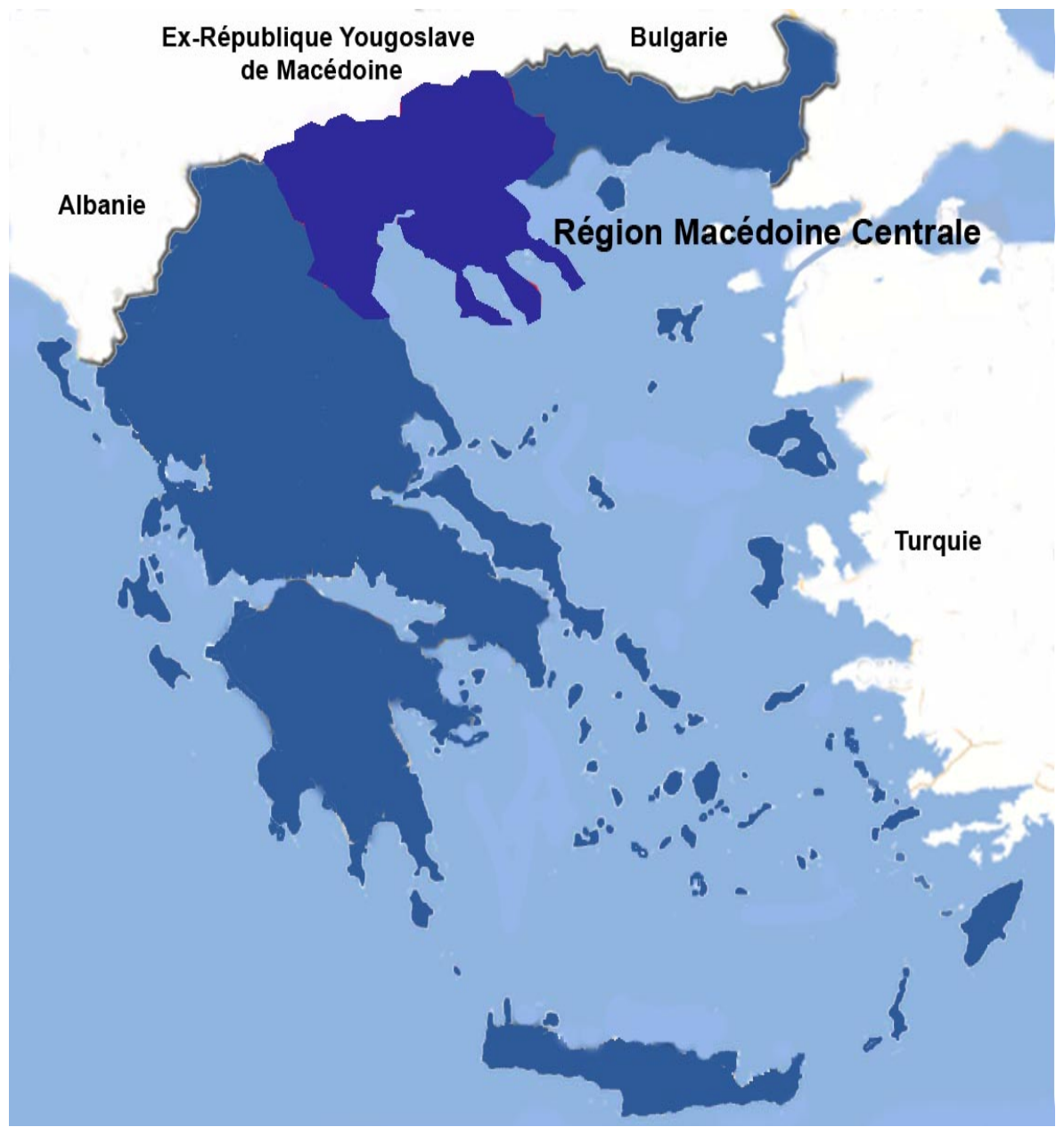

Figure 2. Administrative structure of the region of central Macedonia, in http://www.nath.gr

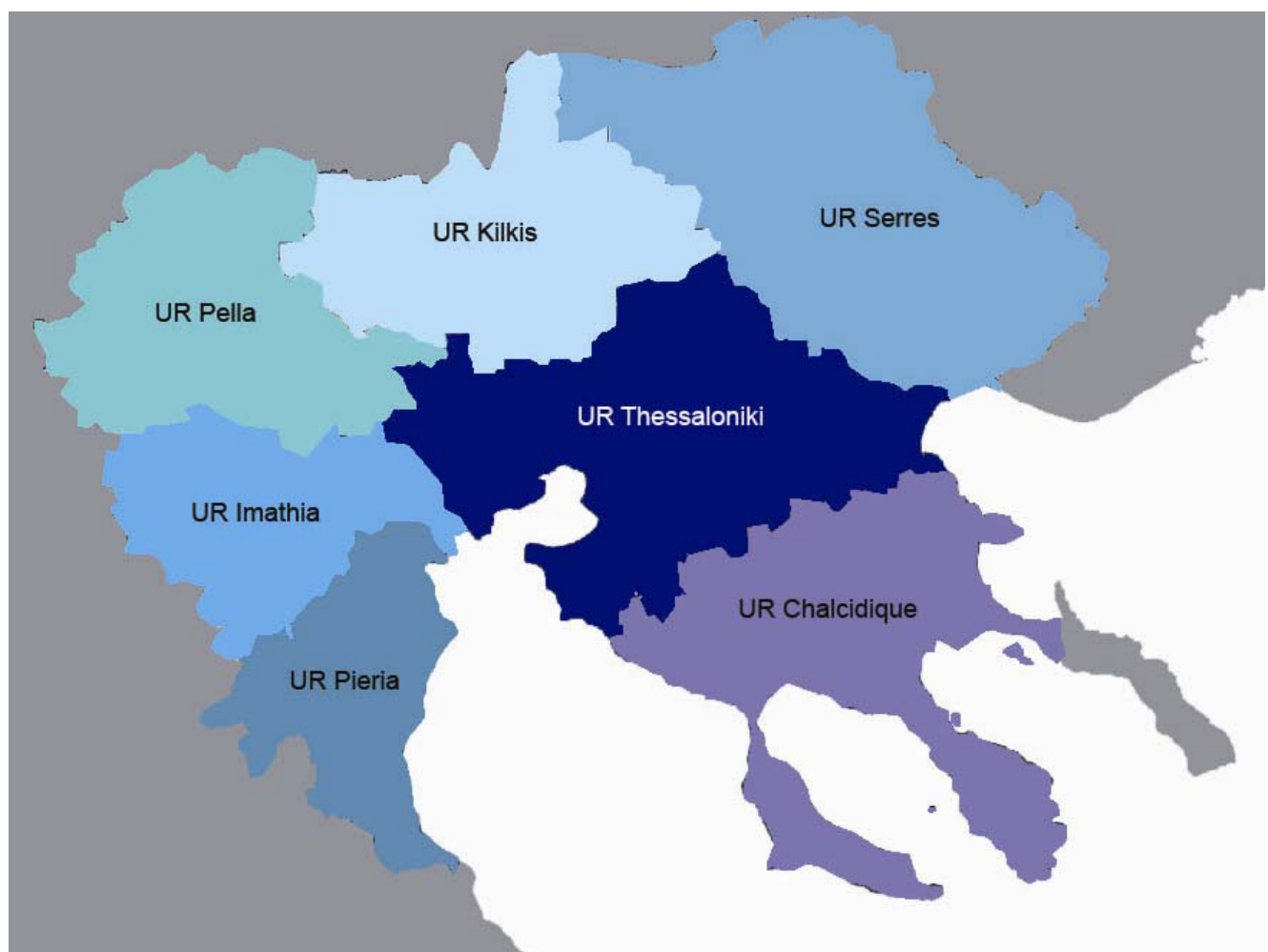


Figure 3. The urban area of Thessaloniki: the city of Thessaloniki, the peri-urban zone and the districts, Thessaloniki's Masterplan (1984), in Matikas, 2010, p. 32.

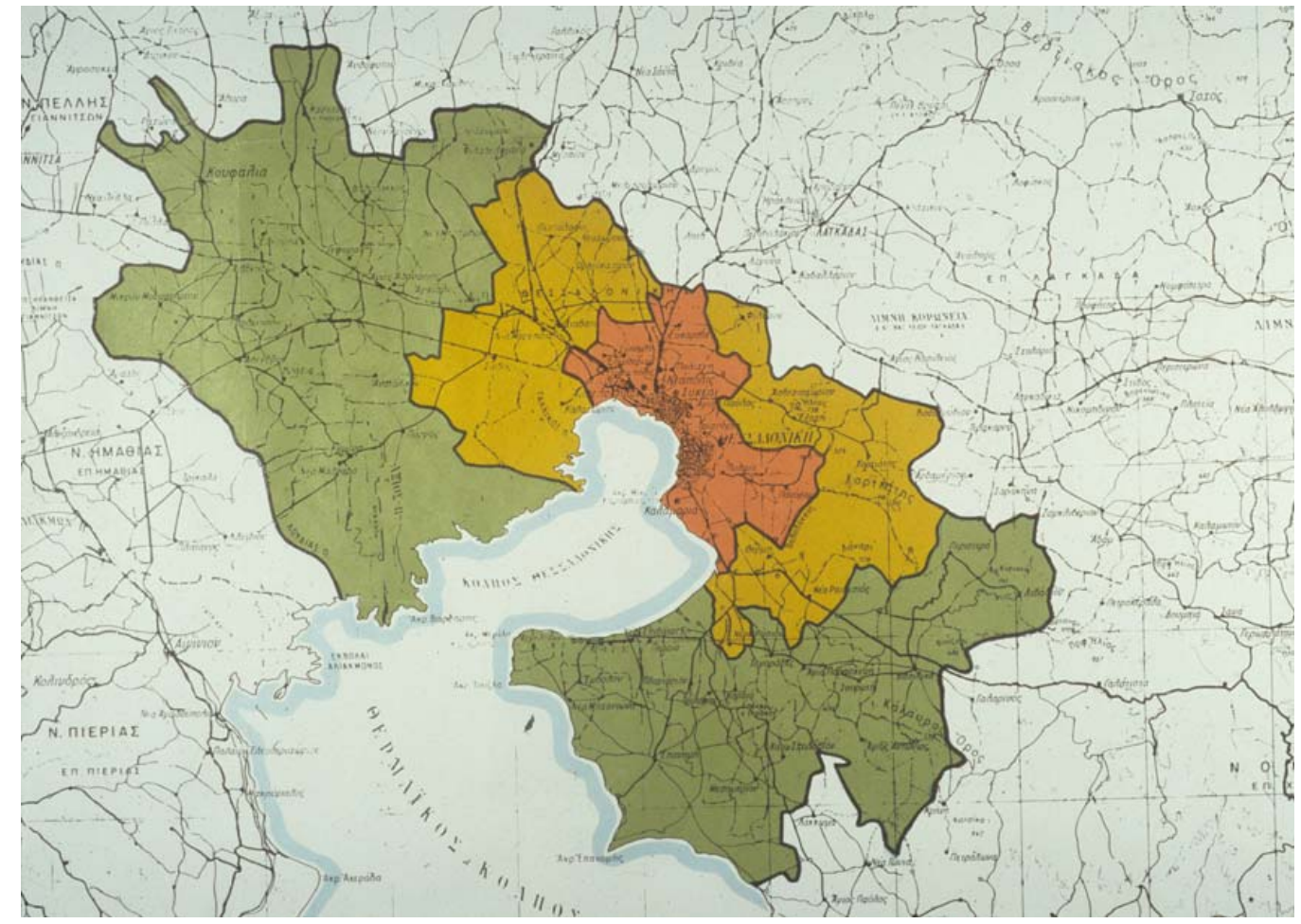

In the second part, the choices of the communal Directives SEVESO I and II [1] are registered and a presentation of basic concepts and elements associated with industrial risk, such as impact thresholds and protection zones (Figure 4), follows. The methods for estimating risks are detected by presenting the international experience. The interest shifts in Greece and especially in institutional settings, recording the establishments Seveso, the economic dimension of respective companies [2] and the correlation of land uses and levels of vulnerability with the affected population [3]. The vulnerability in Thessaloniki is studied and traced by recording (Figure 5) and mapping the SEVESO installations and economically evaluating them in relation to the respective local environment.

Figure 4. Protection zones, in http://www.apsmarche.be/page.aspx?ID=CALCUL_ZONES_RISQUES

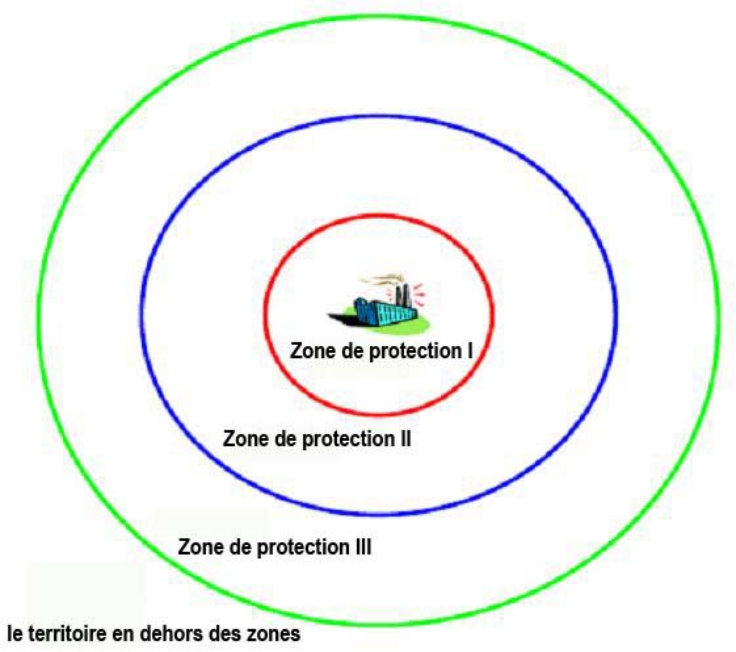


Figure 5. List of SEVESO establishments in the regional unit of Thessaloniki, for which the external emergency plans were developed (2004), and those covered by the Directive SEVESO II (HTL, high threshold and low threshold 2008), in Komninos, p.262

\begin{tabular}{|c|c|c|c|c|c|}
\hline 2004 & $\begin{array}{l}\text { Entreprises - } \\
\text { Plans d'Urgence } \\
\text { externe }(2004)^{\star}\end{array}$ & $\begin{array}{l}\text { s. h. } \\
2008\end{array}$ & $\begin{array}{c}\text { Entreprises - Directive } \\
\text { Seveso II, seuil haut } \\
(2008)^{\star \star}\end{array}$ & $\begin{array}{l}\text { s. b. } \\
2008\end{array}$ & $\begin{array}{c}\text { Entreprises - Directive } \\
\text { Seveso II, seuil bas } \\
(2008)^{\star \star}\end{array}$ \\
\hline 1 & $\begin{array}{l}\text { «Agrotechnica» } \\
\text { Kekridis SA }\end{array}$ & 1 & $\begin{array}{l}\text { "Agrotechnica» Kekridis } \\
\text { SA }\end{array}$ & & \\
\hline 2 & BASF & 2 & BASF AGRO AE SA & & \\
\hline 3 & BP HELLAS & 3 & BP HELLAS & 1 & $\begin{array}{l}\text { BP HELLAS } \\
\text { (Dendropotamos) }\end{array}$ \\
\hline 4 & $\begin{array}{l}\text { JET OIL SA, } \\
\text { (Etablissement à } \\
\text { Kalohori) }\end{array}$ & & - & & \\
\hline 5 & SHELL Gas & 4 & SHELL Gas & & \\
\hline 6 & $\begin{array}{l}\text { SHELL HELLAS SA } \\
\text { (Etablissement à } \\
\text { Kalohori) }\end{array}$ & 5 & $\begin{array}{l}\text { SHELL HELLAS SA } \\
\text { (Etablissement à Kalohori) }\end{array}$ & & \\
\hline 7 & SYGENTA HELLAS & 6 & SYGENTA HELLAS & & \\
\hline 8 & $\begin{array}{l}\text { ALPHA fournitures } \\
\text { agricoles }\end{array}$ & 7 & $\begin{array}{l}\text { ALPHA fournitures } \\
\text { agricoles }\end{array}$ & & \\
\hline 9 & $\begin{array}{l}\text { Industrie des } \\
\text { Engrais Phosphatés } \\
\text { SA (2 } \\
\text { Etablissements) }\end{array}$ & & & & \\
\hline 10 & $\begin{array}{l}\text { EKO (carburants } \\
\text { grecs - huiles, } 2 \\
\text { Etablissement) }\end{array}$ & 8 & EKO (GPL) & 2 & $\begin{array}{l}\text { EKO (2 Etablissement, } \\
\text { Aéroport et Ionia) }\end{array}$ \\
\hline 11 & ELLAGRET & 9 & ELLAGRET & & \\
\hline 12 & $\begin{array}{l}\text { ELPE SA (pétroles } \\
\text { grecs) }\end{array}$ & 10 & $\begin{array}{l}\text { ELPE SA (polypropylène et } \\
\text { carburants) }\end{array}$ & & \\
\hline 13 & Eftimiadis & 11 & Eftimiadis & & \\
\hline 14 & $\begin{array}{l}\text { NITROFARM SA } \\
\text { KIRGIDIS SA }\end{array}$ & & & & \\
\hline 15 & $\begin{array}{l}\text { PAPAIKONOMOU } \\
\text { AGROCHIMIE }\end{array}$ & 12 & $\begin{array}{l}\text { AGROLOGY } \\
\text { PAPAIKONOMOU }\end{array}$ & & \\
\hline 16 & PETROGAZ SA & 13 & PETROGAZ SA & & \\
\hline 17 & $\begin{array}{l}\text { PRIMAGAZ GDL } \\
\text { SA (Etablissement } \\
\text { à Kordelio) }\end{array}$ & & & 3 & PRIMAGAZSA \\
\hline 18 & $\begin{array}{l}\text { FARMA- } \\
\text { CHIMIQUE }\end{array}$ & 14 & FARMA- CHIMIQUE & & \\
\hline \multirow[t]{5}{*}{19} & YPSILON SA & 15 & YPSILON SA & & \\
\hline & - & 16 & VIEKAL SA & & \\
\hline & - & 17 & VITOUMINA AE SA & & \\
\hline & & & & 4 & KIRGIAS \\
\hline & & & & 5 & $\begin{array}{l}\text { AIR LIQUIDE HELLAS } \\
\text { SA }\end{array}$ \\
\hline
\end{tabular}

Furthermore, the research continues with the localization of urban and peri-urban territories affected by the industrial risk (Figure 6), through which it becomes apparent that the biggest problem is logged in Eleftherio Kordelio (Figure 7). After a first general approach, there is a detailed investigation by the General Development Plan and the Urban Study for the conditions creating the problem, its impacts and possible corrective movements in planning, focusing on reducing the effects of an industrial major accident in this region [4]. Finally, a particular reference is made to urban paradox of non-awareness and non-existence (creation) of fauve impact to local residents. 
Figure 6. The SEVESO establishments in Thessaloniki. Municipalities affected by industrial risk: 1. Delta Axiou (municipal unit of Echedoros), 2. Kordelio - Evosmos (municipal unit of Eleftherio Kordelio) and 3. Ampelokipi - Menemeni, in Matikas, 2012, p.118

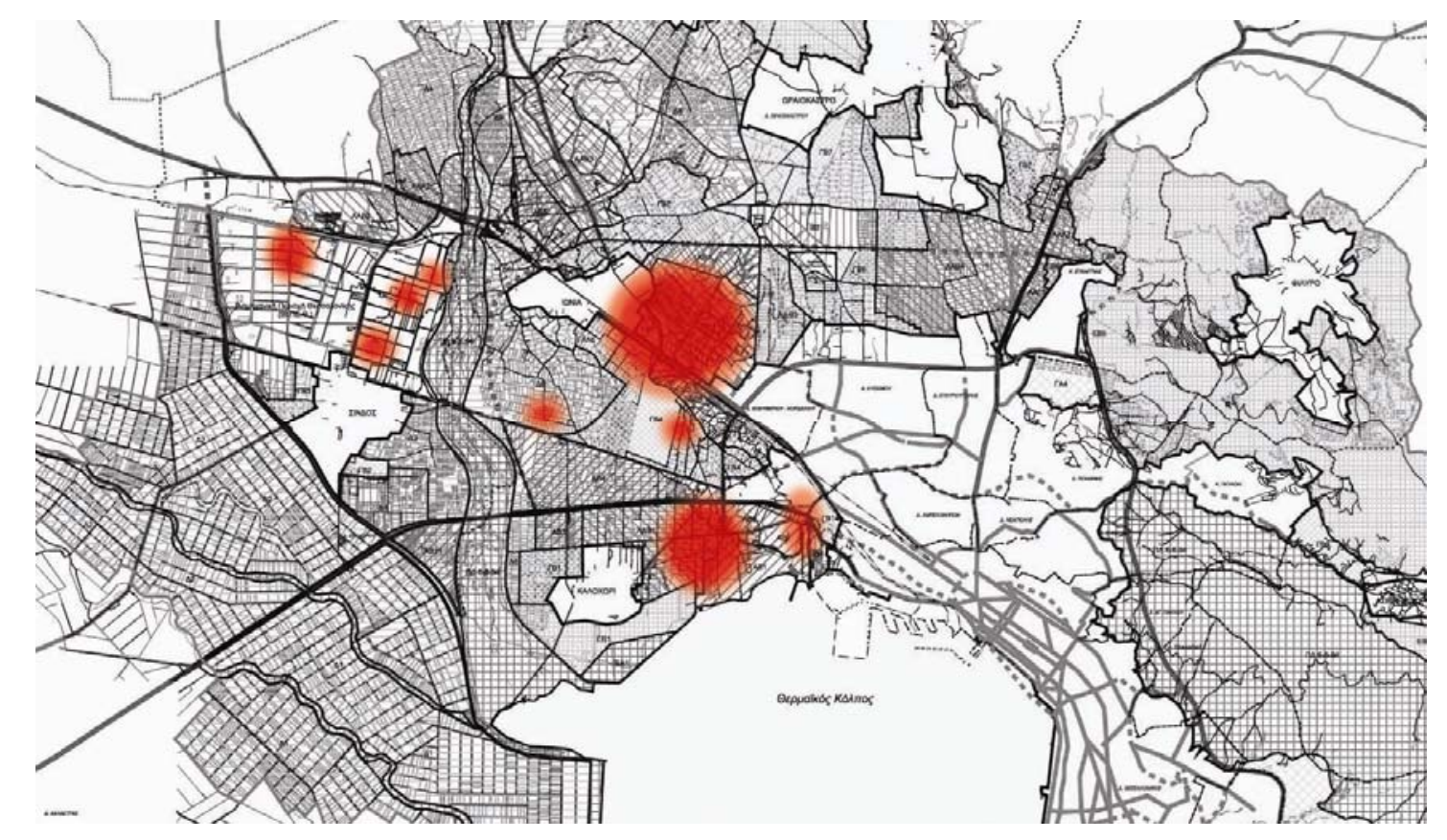

Figure 7. Vulnerability diagram: protection zones I, II and III, in Matikas, 2012, p.117

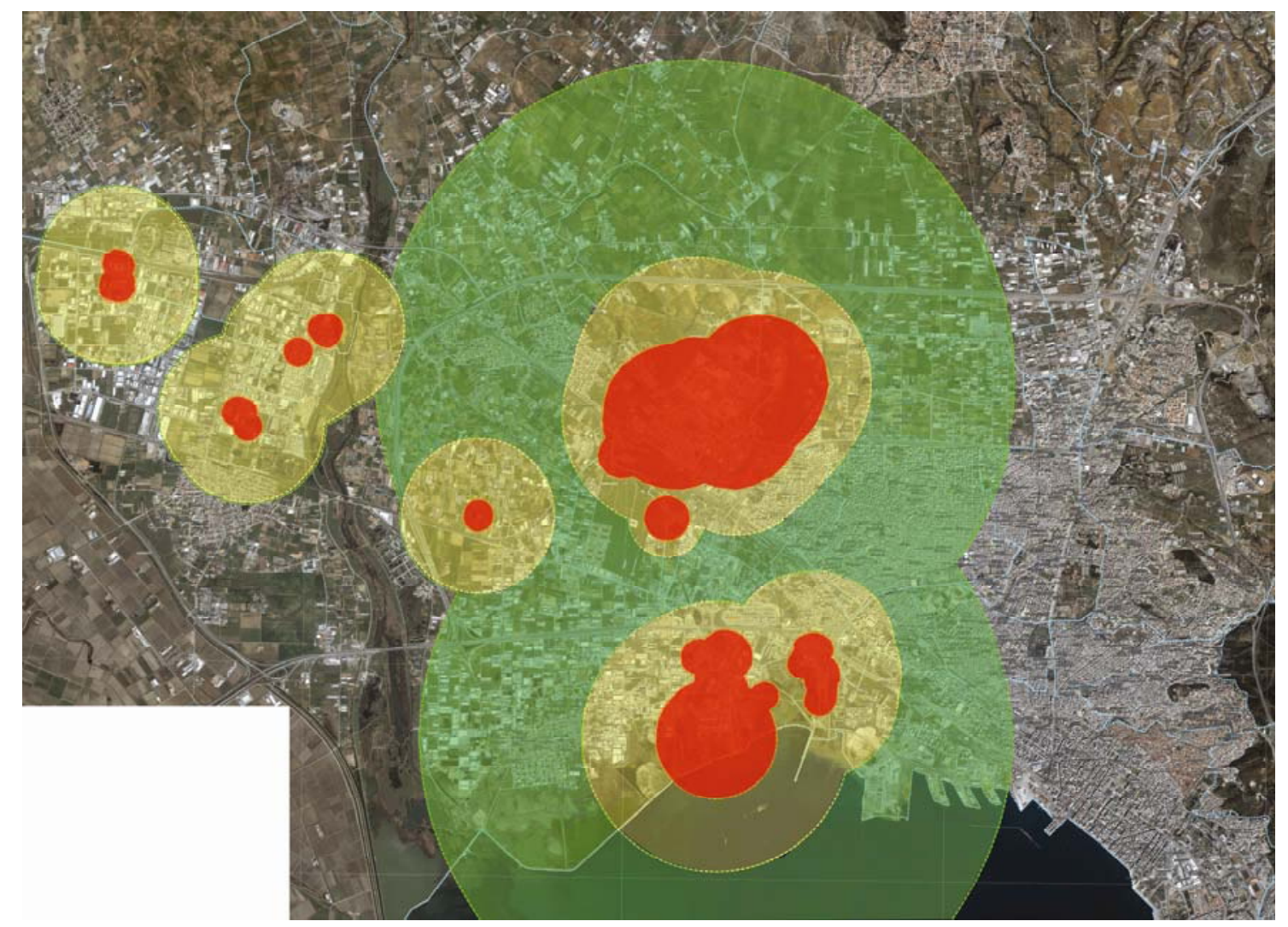

In the third part are approached issues related to urban regeneration. It comes before a general reference to the origin, definition, characteristics, planning, performance, durability and evaluation of specific aspects of urban regeneration in cities of the Mediterranean. Then, a brief reference to 
business opportunities for eliminating the industrial risks in medium and long-term in the region inserts.

In the end, it is proposed an urban regeneration framework able to be applied to areas threatened in western Thessaloniki, comprising: a) the operational framework of the city and the distribution of skills (basic urban services, urban planning and development), b) a description of the project (urban management, intervention on the buildings, redevelopment of public space, awareness, knowledge and communication), c) the status of the project, its progress (beginning, milestones, basic steps, completion) and d) the results, operational targets, initiators (project management), operators, financing tools and evaluation.

This survey revealed a number of general conclusions that directly or indirectly provide answers to both questions posed in the introduction and in other series that arose during the course. Specifically:

In Thessaloniki the embrace of urban area and industry, that can cause a major accident, emerged gradually after 1960 from the absence of planning and social housing policy, which led to the uncontrolled expansion of urban fabric through the illegal building.

The industrial tradition of the city is important. The secondary played and continues to play a key role in its development. In Thessaloniki are identified 22 establishments SEVESO, of which 17 are of high-threshold logic (HTL). The SEVESO industries of the city participate with $2.9 \%$ in gross value added (GVA) of the districts [2] and 0.44 in GVA total of the country. The percentage is enlarged if businesses that depend on them are included.

The risk of major accident consequences in western districts, as reflected in mapping of protection zones I and mainly II, covers a large proportion of their size with comparable population. Avoiding the elementary residents' information, concerning the security measures and the appropriate behavior to adopt in case of a MA, leads to non-appearance of fauve impact, despite their absolute exposure to the threat.

Avoiding the institutionalization of a method to determine the protection zones, the nonactualization of External Emergency Plans since 2004, which are responsibility of the state, and even the denial of access of the design-planning services to relevant information, to integrate the parameter of industrial risk in urban planning [4] confirms the gravity of the problem.

The Directives SEVESO, which are obviously important, avoid referring to cases such as this. The exhortation to member-states, to take into consideration in their allocation policy or their land use objectives of prevention and limitation of major accidents' consequences, does not cover the existing urban vicinity between the urban continuum and the hazardous industries.

\subsection{Risk Reduction Parameters}

The only way to reduce risk is to intervene in industries. There are four aspects of reduction: a) the readiness and training of their employees so as they can face the problem (how to react, to handle a crucial situation), before it spreads, b) the use of the best technology, c) the removal of certain installations and finally d) the removal of entire establishment. The first parameter is ignored by the determinist method, which favored for calculating protection zones in Greece.

Forcing SEVESO industries to reduce the vulnerability of installations is a responsibility of national political leaderships. The latest, considering the effects on local and national economy and without social pressure, prefer to ignore the issue. Even after the major accident of Jet Oil (Figure 8) in 
Western peri-urban zone of Thessaloniki in 1986 and the other of Petrola in Athens in 1992 (Figure 9), with 13 deaths and 15 wounded, no effort was made to reduce the threat.

Figure 8. Conflagration of «JET OIL» in Kalohori, Thessaloniki, on February the $24^{\text {th }}$ of 1986, in http://ecology-salonika.org/2010/02/24/jet-oil-25-years-after/

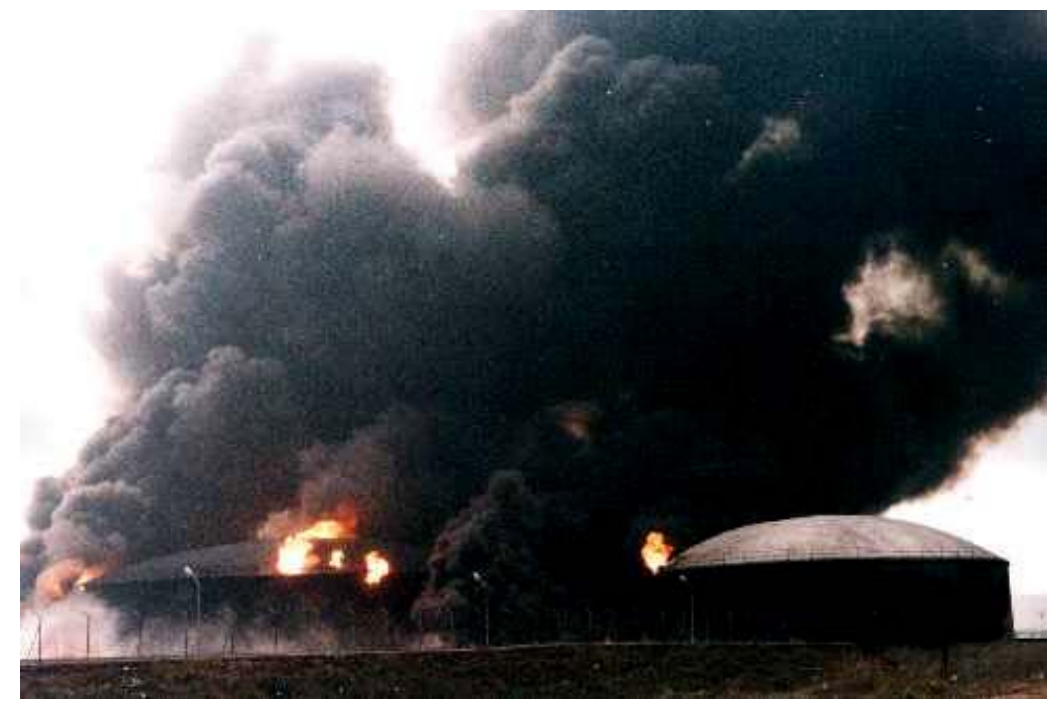

Figure 9. The major accident of Petrola in Athens in 1992

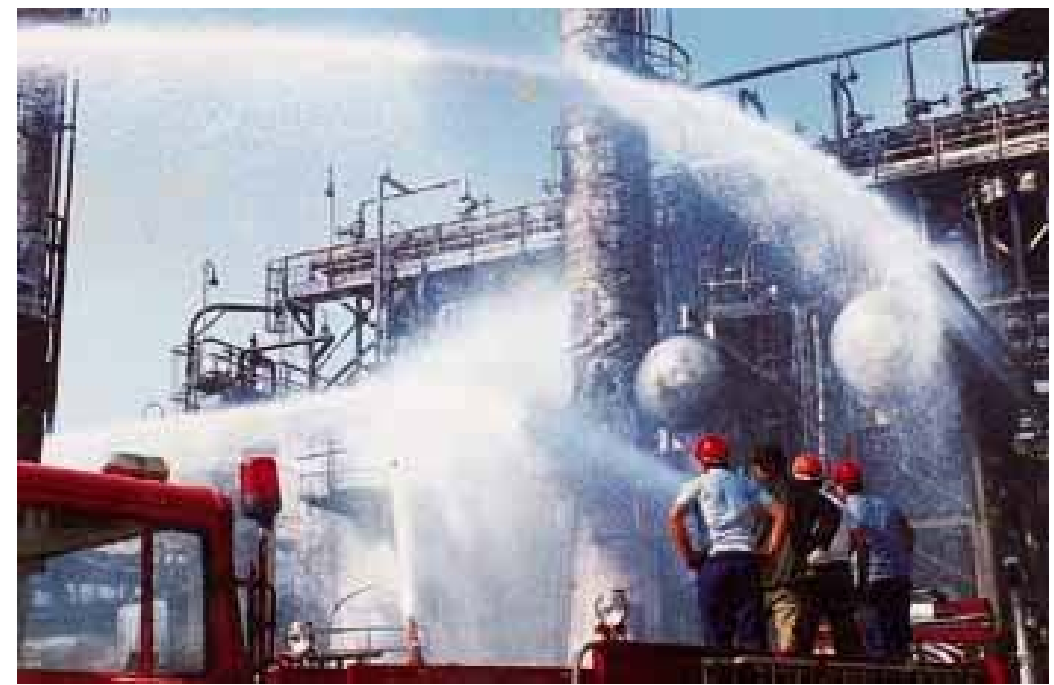

\subsection{The real threat today and the corresponding solutions for the municipal unit of E. Kordelio}

The risks, to which the urban area is exposed and for which precautionary protection measures should be taken, are: a) the presence of toxic substances in the air, b) the thermal radiation and c) the wave of high pressure.

In urban areas covered by protection zone I, such as the urban unit 5 of the municipal unit of E. Kordelio (Figure 10), the expected consequences of a major accident are: possible deaths by inhalation of toxic substances in $50 \%$ of the population, third degree burns by heat radiation to more than $50 \%$ of the population and $50 \%$ of exterior walls damaged by the wave of high pressure. It is understood that for these areas there is no preventive measures for protection and the only solution is the immediate removal of population, combined perhaps with the installation of productive activities. 
Figure 10. The urban units 4 et 5 of Eleftherio Kordelio, included in protection zones I and II, in Matikas, 2012, p.125

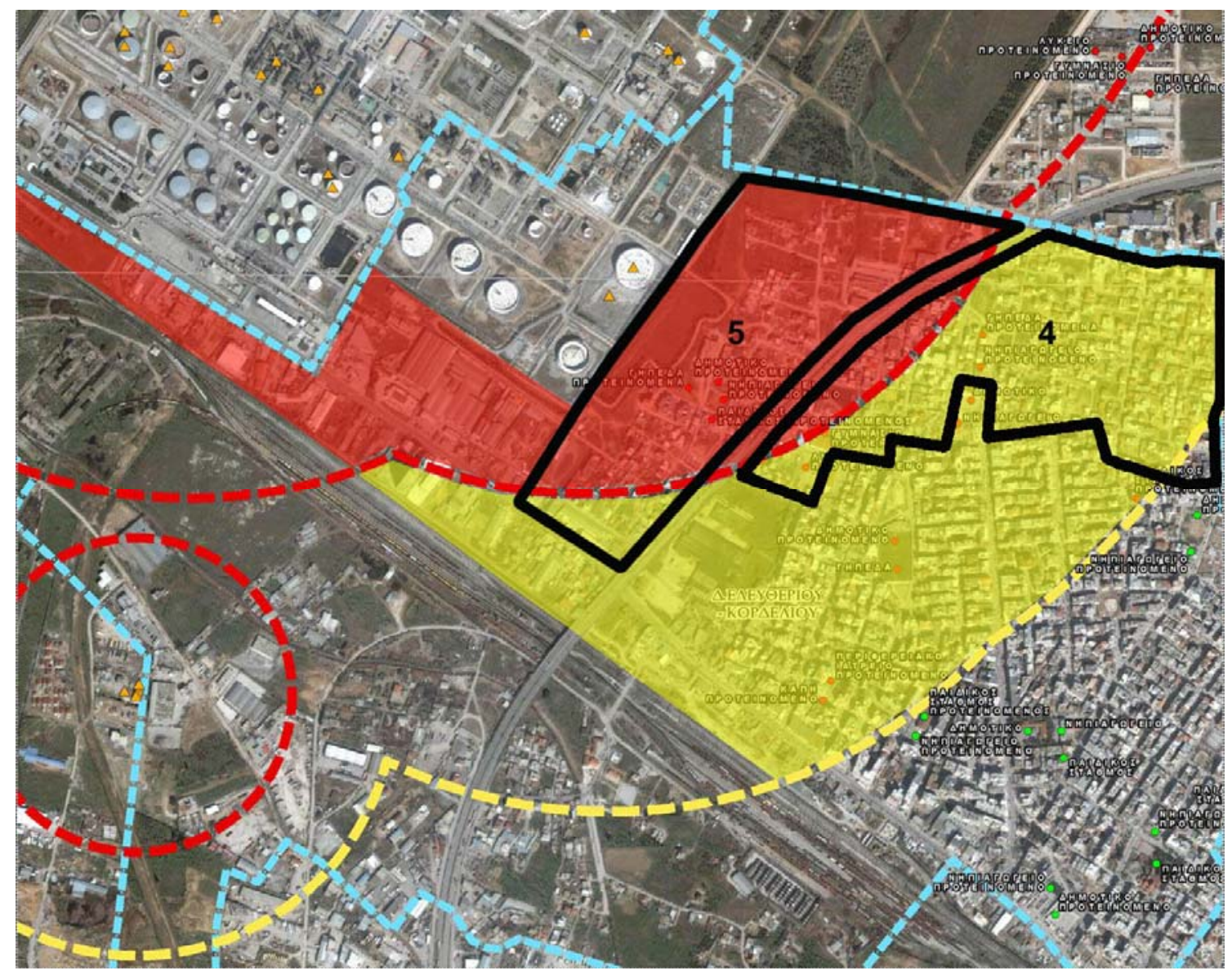

In areas of urban fabric covered by protection zone II, such as the urban unit 4 of the municipal unit of E. Kordelio, the expected consequences of a major accident are: possible deaths by inhalation of toxic substances in $1 \%$ of the population, third degree burns by heat radiation in $1 \%$ of the population, collapse of roofs, doors and walls damaged by the wave of high pressure. In these cases intends the application of external emergency plans and also specific interventions proposed in the urban regeneration framework.

\subsection{The role of urban planning}

It is obvious that a generalized effort to implement the urban regeneration framework with interventions and actions selected for the urban unit 4 of E. Kordelio (Figures 11, 12), in any territory of Western Thessaloniki covered by the protection zone II, is impractical, undesirable, economically unthinkable and therefore visionary.

Figure $11 \& 12$. The proximity of new buildings to SEVESO installations 

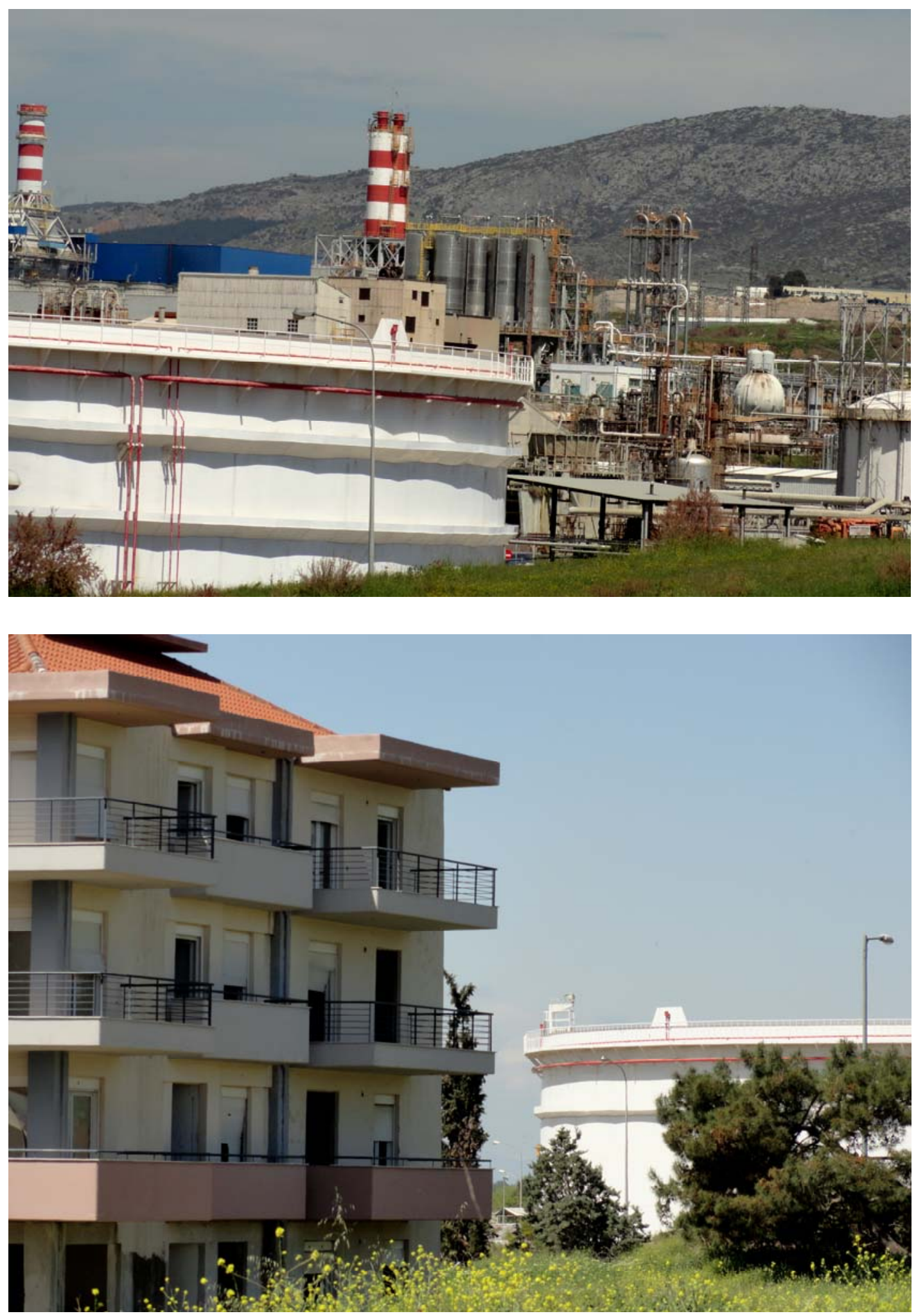

According to the above, in respective cases of immediate proximity of urban areas and SEVESO industries, the main interest focuses on risk reduction facilities inside the installations, so that protection zone II does not cover urban areas. At the same time, adjustments of urban character are required both for the surrounding areas and the nearest urban fabric. Even in cases where the target is achieved completely, urban planning must take into account the parameter of industrial risk.

\section{Conclusions}


Unfortunately, until today the issue of industrial risk and its relationship with urban planning has not piqued the interest of urbanists. While there are a vast number of scientific publications of experts for the issue, it is quite difficult to find relevant publications of those who study the planning of the urban space. The installation of new SEVESO industries or their relocation to an industrial district organized under a modern planning in a sufficient distance (far away) from the urban fabric, in a territory selected with criteria that allows the optimal service of the necessary networks and their economic development, does not mean that eliminates fundamentally their vulnerability.

Even if dispersion models are used, it can not be perfectly predicted where the toxic substances will head, nor which will be the consequences of a leak in the ground and thus groundwater and in the food chain. Even more, there have not been adequately studied the impacts in medium and long-term of an industrial accident in the environment, in fauna, flora, wetlands, coastal areas, protected areas and ecosystems. Risk management is not a fact and it must not be taken for granted. Perhaps it is finally time for progress to get another form, based on renewable energy, while changing the way we design and produce urban space.

\section{Conflict of Interest}

"The authors declare no conflict of interest".

\section{References and Notes}

1. Union Européenne, Directives SEVESO I (82/501/CEE) et II (96/82/CE): http://europa.eu/legislation_summaries/environment/civil_protection/121215_en.htm

2. Komninos, N. (responsable scientifique), Georgiou, Chr., Martzopoulou, N., Martinidis, G., Tramantzas, C., Sefertzi, E. L'Avenir de l'Industrie à Thessaloniki, Rapport Final de Recherche, OR.THE., Thessaloniki, Greece, 2009

3. Ziomas I. (responsable scientifique), Aggelis E., Giannakou A., Eppas D., Kosmidis E., Ntemiri S., Progiou A., Sebos I., Stefanidou E., Symeonidis P. Risque Industriel et Interventions Urbaines, Rapport Final de Recherche, OR.THE., Thessaloniki, Greece, 2009

4. Matikas, C. Le Risque Industriel à Thessaloniki. Proposition d'un Cadre de Régénération Urbaine Appropriée, Mémoire de Recherche, Paris, France, 2012

(C) 2011 by the authors; licensee MDPI, Basel, Switzerland. This article is an open access article distributed under the terms and conditions of the Creative Commons Attribution license (http://creativecommons.org/licenses/by/3.0/). 